\title{
Utilization of Environmental Knowledge for Watershed Management in Northern Michigan
}

DONALD C. PELZ

Center for Research on Utilization of Scientific Knowledge

Institute for Social Research

The University of Michigan

Ann Arbor, Ml 48106

\section{JOHN E. GANNON}

Research Center

State University of New York

Oswego, NY 13126

ABSTRACT / The Northern Michigan Environmental Research Program was conducted by the University of Michigan's Biological Station and Institute for Social Research to obtain information about the aquatic and human resources of water-rich, resort-ori- ented northern lower Michigan. Results of the study were directed toward long-term environmental management. Multiple methods were used to communicate study results, including self-contained information briefs, regular contacts and seminars with community leaders and public officials, and mass media. Selected illustrations of project data applied to environmental management problems are cited, e.g., curtailment of nutrient loadings, wetlands protection, improved effectiveness of riparian organizations, and highway planning. A series of short Lakeland Reports, designed to present factual information, general environmental principles, and action implications to a lay audience, proved to be effective. However, it became apparent that environmental decisions were not strongly affected by reports alone. Instead, several mutually reinforcing channels of communication must be employed to develop a climate of receptiveness and understanding to insure environmentally sound decisions.
When the last glaciers retreated from the north central Great Lakes region of the United States, they left a legacy of thousands of inland lakes and connecting streams. These waters are an enormous natural resource for both human recreation and wildlife propagation. The northern half of Michigan's lower peninsula is typical of this terrain, bounded on the west by Lake Michigan, on the north by the Straits of Mackinac, and on the east by Lake Huron and dotted with many inland lakes. For generations this region has provided a vacation retreat for city dwellers from the urbanized corridor stretching from Detroit and Toledo through southern Michigan, Ohio, Indiana, and Illinois to Chicago.

The water quality of the lakes in the northern part of Michigan's lower peninsula is still, with scattered exceptions, excellent. Pressures from human use are increasing, however. Evidence of eutrophication in many lakes and streams the shores of which are heavily populated in the lower portion of the state gives witness to potential dangers for the more northerly waters.

Under a 5-year grant from the National Science Foundation's RANN program (Research Applied to National Needs, 1972-1976), the University of Michigan Biological Station joined with the University's Institute for Social Research (ISR) to conduct the Northern Michigan Environmental Research Program (NMERP). Aims of the program

\footnotetext{
KEY WORDS: Water quality, Lake Management, Planning, Watershed Management
}

were to study the inland lakes, the surrounding land, and the attitudes of both seasonal and year-round residents in the two-county area surrounding the Biological Station (Fig. 1) and to encourage the use of this information in actions applied to safeguarding the area's natural environment. The three interdisciplinary research thrusts of the program were:

1). Aquatic. Water, quality characteristics of 38 inland lakes in the study area, under the direction of limnologist John E. Gannon, Associate Research Scientist in residence at the Biological Station and coprincipal investigator

2). Terrestrial. Characteristics of the land, especially nutrients in ground-water and precipitation, under the direction of Curtis J. Richardson, Assistant Professor of Resource Ecology, School of Natural Resources

3). Social. Characteristics and attitudes of the residents, under direction of Robert W. Marans, Research Scientist, Survey Research Center, ISR, and Associate Professor of Architecture and Urban Planning

Communication and utilization of environmental knowledge was an integral concern of the project from its inception, with special attention from Mark W. Paddock, Assistant to the Director and coprincipal investigator, who planned a systematic outreach to community leaders and news media. In 1975 the three research components were supplemented by a fourth, emphasizing utilization, under the direction of Donald C. Pelz, Director, Center for Re(C) 1979 Springer-Verlag New York Inc. 


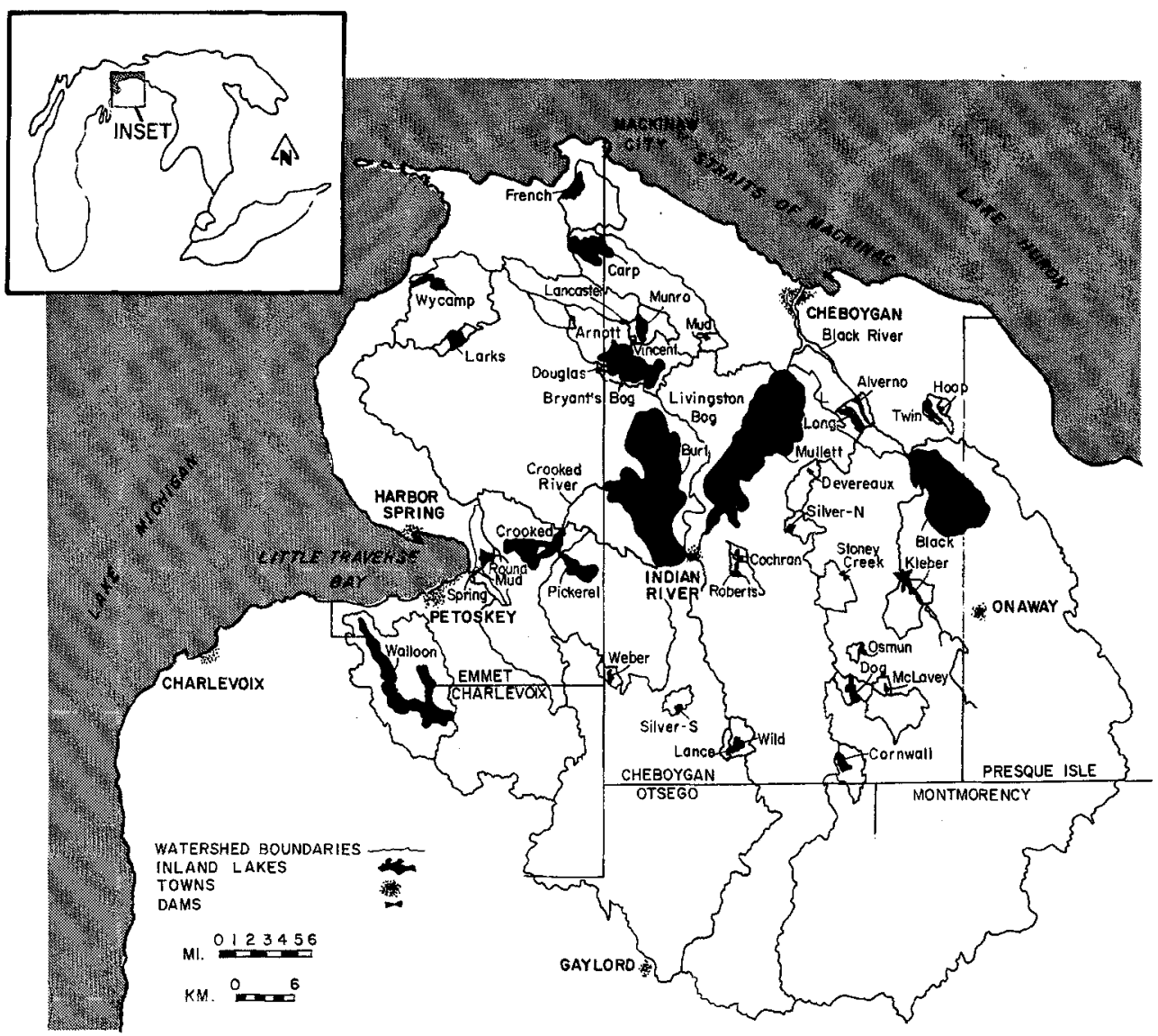

Figure 1. The inland lakes and their watersheds under investigation by the Northern Michigan Environmental Research Program.

search on Utilization of Scientific Knowledge (CRUSK), ISR.

The quality of inland waters is affected by thousands of private, individual actions the total impact of which is only slowly visible. Other actions affecting the environment are of more public and visible character, as exemplified by public hearings and decisions by official bodies. In both cases Biological Station staff directed their environmental information to individuals, forums, and public decisionmaking bodies.

The purpose of this article is to highlight principles of knowledge utilization as applied by the staff to watershed management problems. Examples are largely drawn from a "knowledge utilization (KU) activity log" maintained by William L. Foster, Public Information Scientist for the Biological Station 1973-1976, as documented in a technical report (Pelz 1977)., Utilization activities were continued in the summer of 1977 as Project CLEAR (Community Lakes Environmental Awareness Research) by a group of dedicated students under the direction of Art Gold. A further effort in communication was launched in the fall of 1977

'In this technical report, describing knowledge utilization in NMERP, appendices include the full text of nine Lakeland Reports and Walloon Lake Profile and excerpts from other information outputs. A copy may be obtained (with payment of \$6.00) from: Director, CRUSK/ISR, P.O. Box 1248, University of Michigan, Ann Arbor, Mich. 48106. 
with a National Science Foundation grant under the direction of John E. Gannon and Art Gold.

\section{Perspectives on Knowledge and on Utilization}

In examining the utilization of knowledge from this project, it is helpful to recognize some distinctions between types of knowledge involved on a broad spectrum, from "hard" to "soft," and between modes of using this knowledge, e.g., "instrumental" and "'conceptual" uses.

Caplan and others $(1975 ;$ p. 18) noted a distinction between two broad types of social science information: hard knowledge- "research-based, usually quantitative, and couched in scientific language," and soft knowledge"nonresearch based, qualitative, and couched in lay language."

There is no distinct boundary between hard and soft information, of course. In this investigation, hard knowledge was represented in factual information about parameters of inland lakes, characteristics of adjacent soils, and the behavior and opinions of area residents. Soft knowledge was represented in the meaning of terms such as "eutrophication" and "nutrient loading," concepts like "wetlands" and their importance for lake quality, and principles such as the relationship between the use of lawn fertilizers and the growth of algae.

Rich (1977) found it important to differentiate between what he termed "knowledge for action" (instrumental use) and "knowledge for understanding" (conceptual). "Instrumental use" refers to those cases where information is being used for specific decision-making and problem-solving purposes. Conceptual use refers to influencing a policy maker's thinking about an issue without putting information to any specific, documentable application.

An instrumental use may be illustrated by a specific action that is clearly designated, such as adoption of a wetlands ordinance or a decision for or against installation of a sewer. A conceptual use may be illustrated by some evidence of change in awareness, thinking, or understanding, as manifested, e.g., in public testimony on a wetlands ordinance or sewer. The distinction is not sharp. If the evidence persuades a decision maker to adopt option $A$ instead of $B$, the use is clearly instrumental. If he or she has already adopted option B and the evidence reinforces his or her belief in this option, the use is more properly called conceptual.

In joint working papers (Caplan and Rich 1976; Rich and Caplan 1976) these authors traced the shortcomings of a traditional input/output model of information use, which assumes a one-to-one matching between input and output.
They found that policy makers reported a nontraditional perspective, in which both hard and soft knowledge accumulated through time in a broad framework of understanding about a policy area (conceptual use), and specific decisions were then made within this context (instrumental use). They proposed a matrix with the following features:

\begin{tabular}{|c|c|c|}
\hline \multirow{3}{*}{$\begin{array}{l}\text { Mode of utilization } \\
\text { Instrumental }\end{array}$} & \multicolumn{2}{|c|}{ Type of knowledge } \\
\hline & Hard. & ....Soft \\
\hline & A & B \\
\hline Conceptual & $\mathrm{C}$ & $\mathrm{D}$ \\
\hline
\end{tabular}

In this matrix the traditional perspective considers knowledge to have been usd only in cell $A$, when a hard form of information is applied as input to an instrumental use as output. As a simple illustration from NMERP, in July 1975 the appearance of a white residue on the skin of swimmers in Lake Charlevoix prompted the closing of beaches by health authorities; when a sample was analyzed by the Biological Station and found to be marl (calcium carbonate), this hard information permitted the beaches to be reopened (instrumental use).

As an illustration of cell $\mathrm{D}$, the concept of wetlands and their ecological value (soft knowledge) was recognized by planners in one township as important for rational development and incorporated in the draft of a zoning ordinance (conceptual use). Cell B is illustrated when this ordinance was adopted by vote of township residents (instrumental use). Other illustrations of the' four cells will be given in a later section.

\section{Forms and Channels of Communication}

\section{Personal Interaction with "Stakeholders'"}

From its inception the Northern Michigan Environmental Research Program established communication with numerous individuals and groups who had an investment or "stake" in the study area. An early task was to compile a listing of some 300 stakeholders_potential users of natural resources information at levels of village, township, city, region, and state. From this list a group of three dozen "community leaders"' was assembled, including:

Township officers Soil conservationists

County commissioners Fish and game biologists

Planning officials Foresters

Zoning officials Extension directors

District sanitarians Lake association officers

Water resource managers Concerned environmentalists

During 1972-1976 five meetings were held with this group to solicit objectives for the research, review plans, 
and react to progress reports. Out of these contacts there developed a listing of 400 individuals who periodically received mailings of written materials.

In addition, members of the Biological Station staff regularly attended meetings of planning commissions in both counties and made personal contacts or visited with groups that included (during 1974-1976) 24 public bodies, 14 lake associations, 18 other civic groups, a sanitary engineering firm, and numerous individuals.

\section{Individual Packages}

To communicate with its stakeholders, the staff prepared a series of nine Lakeland Reports of 4-8 pages each and disseminated them in various ways: Copies were sent to the people on the Biological Station's mailing list; lake associations bought or reproduced copies for distribution to their memberships; copies were handed out at meetings of local groups; and portions were incorporated in newspaper articles or in documents prepared for local decision makers.

These reports and other brief "information packages" (see Appendix) were shaped by a series of familiar communication principles. (a) Nontechnical stakeholders are more likely to absorb information in small, digestible chunks. Hence each package was brief and self-contained. (b) General concepts are easier to grasp than factual details. Each of the reports therefore stressed a few broad principles. (c) Each report should permit personal identification. Specific information on local lakes, lands, and residents was emphasized. (d) Information is better grasped if the individual can see some implication for action. Therefore, the reports stressed management options that could be instituted by individuals and communities. (e) Following an obvious guideline, the information packages made liberal use of illustrations-photographs, maps, charts-to provide a contrast to words and numbers. (f) Finally, readers learn more if they are active rather than passive. To stimulate active involvement, several of the Lakeland Reports had brief quizzes with which readers could test their understanding.

Results of a questionnaire sent to the readership indicated that the brief format of the reports and the interspersing of facts with illustrations, principles, and action implications had succeeded in capturing reader involvement (see Pelz 1977, pp. 59-73).

Another type of information package is illustrated by the Walloon Lake Profile, prepared under sponsorship of the Walloon Lake Association, which paid for printing and distributed copies to its members. Beginning with notes on the social history of the lake and its geology, the profile presented a variety of hard information on the lake's residents (from the social survey) and water quality (from the aquatic research) and soft information about protective steps.

To provide a framework of concepts and principles (soft information) for understanding northern Michigan lakes, the NMERP staff prepared a primer on lake ecology and management (Say and others 1975). ${ }^{2}$ This publication, a revision of a document originally prepared for a southern Michigan watershed council (Fulton and Say 1971), was offered at a nominal charge, colorfully illustrated, and set in large type for easy reading by laypersons. The handbook covers inland lake ecosystems, eutrophication, the importance of watersheds, the effects of human use on lakes, and suggestions on what citizen groups can do to protect inland lakes.

\section{Mass Media}

Information about NMERP was disseminated through the mass media in several forms. (a) One form consisted of articles prepared by Biological Station staff for publication in local newspapers, including a periodic column. They were essentially another type of condensed information package. (b) Closely related were articles in the mass media which summarized or reprinted information outputs from the station. For example, a booklet by Foster published in $1976^{3}$ containing hard information on the geologic history, vegetation, and soils of the area was reprinted in several installments in the Cheboygan Daily Tribune, July 1976. Lakeland Report No. 8 on nutrients from human use was summarized and one chart reproduced in the North Woods Call, February 1976. (c) In a third category were news articles about examples of knowledge use, as described below, such as public hearings on the discharge of nutrients from a fish hatchery. (d) The remaining form comprised general reports about the NMERP in local newspapers and radio/ TV, as well as media in Detroit and Ann Arbor, Michigan. During 1972-1976, over 80 items appeared in the four categories.

\section{Intermediate Transformation of Information}

There were many instances in which information went through a series of intermediate forms before conceptual or instrumental use occurred. From the original sources (technical data or technical reports, knowledge and experience in the heads of the investigators), a first transformation was likely to be a Lakeland Report, a staff-authored article appearing in a local paper, or staff testimony at a public hear-

\footnotetext{
${ }^{2}$ May be obtained (with prepayment of $\$ 1.00$ ) from: Director, Biological Station, University of Michigan, Ann Arbor, Mich. 48109.

${ }^{3}$ Original is out of print. A revised edition (Foster 1977) may be obtained (with prepayment of \$0.75) from: Director, Biological Station, University of Michigan, Ann Arbor, Mich. 48109.
} 
ing. Subsequent transformations are illustrated, e.g., when a lake association reproduced a Lakeland Report for mailing to its membership, when a newspaper condensed a Biological Station report in an article, or when these materials were incorporated in background documents for decision makers. Further transformations occurred in the preparation of policy statements (a form of conceptual use) and in the adoption of a specific management decision (an instrumental use). Through a variety of such intermediate transformations, the original information in simplified form reached a much wider audience.

\section{Illustrative Examples-Cases of Knowledge Utilization}

Summarized here are selected examples in which hard or soft information prepared by the Biological Station has resulted in either instrumental or conceptual use.

\section{Fish Hatchery}

For many years the Fisheries Division of the Department of Natural Resources (DNR) has operated a hatchery at Oden, the effluent of which is discharged into Crooked Lake by a small stream. Bacterial action on fish feces and uneaten food releases large amounts of nutrients. Crooked Lake has been identified by the Biological Station as the most seriously affected by human impact of the 38 lakes in the study area and has been the first in the area to install a sewer along one shore (fall 1975).

In February 1975 the Pickerel and Crooked Lakes Improvement Association contacted the Station regarding an application by the Michigan Department of Natural Resources for a permit under the National Pollution Discharge Elimination System to continue discharging the hatchery effluent into Crooked Lake. At a public hearing in August on the proposed permit, John Gannon presented a statement that the stream below the hatchery was nutrient enriched. In January 1976 the DNR Water Resources Commission issued a directive for an $80 \%$ reduction by July 1,1977 in the then current discharge of 0.2 ppm of phosphorus - an amount estimated by the DNR Water Quality Control Division as equivalent to 4 tons of $20 \%$ commercial phosphorus fertilizer per year.

Use of knowledge often arouses controversy, and the Oden Hatchery is a good illustration. The Fisheries Division head denied that phosporus outflow was seriously affecting the lake, asserted that the hatchery water was "99 $44 / 100$ percent pure," and called an $80 \%$ reduction "not technically feasible."

In June 1976 the Station sent a report on nutrient discharge into Crooked Lake to the Water Resources Commis- sion, indicating that the hatchery creek accounted for 60 $80 \%$ of the phosphorus from all streams entering the lake and $40-50 \%$ of the phosphorus from all sources (Gannon and Mazur 1976). In late June the Fisheries Division reached the decision to change the Oden facility from fish hatching (fry and fingerling production) to maintenance of brood stock, with substantial reduction in nutrient output.

In the information/use matrix displayed earlier, this resolution on the fish hatchery is a clear example of cell $A$, where factual (hard) information entered into a specific decision (instrumental use).

Other cells of the matrix can be illustrated by related events on Crooked Lake. Gannon's original testimony in August 1975 was soft information on organic pollution (hard information on nutrient loadings from various sources was not available until the following June). If this affected the January 1976 order to reduce phosphorus output by $80 \%$, it would illustrate cell $B$.

The Pickerel and Crooked Lakes Improvement Association for several years has welcomed assistance from the Biological Station. Crooked Lake was one of the earliest in the area to be developed, and many of its septic systems were deteriorated or overloaded. Its beaches had been closed on several occasions by the health department for excessive coliform bacteria counts, and residential construction was blocked until a sewer system was available. In November 1973 the association prepared for its membership a brochure, "Will We Save Our Lakes? The Time for Decision is Now," on environmental protection, including 15 pages from the Biological Station with hard and soft information on water quality, wetlands, shoreline vegetation, and surrounding soils. This information stimulated awareness of ecologic principles among the members. A concrete symptom of this concern was a series of steps by the Springvale Township Planning and Zoning Commission (summer 1975) to draft an ordinance establishing a greenbelt of natural vegetation along adjoining riverbanks. Such a draft may be considered a conceptual use of both hard and soft information and an illustration of cells $\mathrm{C}$ and D. (In these illustrations we have chosen to call the preparation of a policy proposal or draft an example of conceptual use, and the formal adoption of such a policy an example of instrumental use.)

\section{Burt Township Ordinance}

The largest lake in the study area is Burt, the northern half of which lies within Burt Township. The Burt Township Association is one of the most active lake groups in the area. The township's Planning and Zoning Commission has had a long-standing concern for controlling population growth and attendant development. Following preparation 
of a land-use plan adopted in 1974, the commission undertook to write a township zoning ordinance including a section on wetlands-defined as an area the surface of which was within $4 \mathrm{ft}$ of the water table. The rationale of wetlands was explicitly incorporated in the ordinance draft:

These areas are not suited for general use or habitation by people because preparation for such use requires that the land be dredged, filled, cleared, excavated and drained. These operations destroy the character of natural wetlands and their functions of removing nutrients, retarding sediments, maintaining shoreline, and fostering wildlife, and consequently they lower the quality of the waters. ${ }^{4}$

This action illustrated cell $D$ in the information/use matrix, since the knowledge was soft (general principles), and its incorporation in a proposed ordinance was conceptual use.

The ordinance was provisionally approved by the township board in May 1976, and to assure public backing it was submitted to public referendum in August. When voters approved it, an example of instrumental use in cell B occurred.

The Burt township zoning ordinance was the outcome of years of dedicated leadership and cultivation of local opinion. According to the former planning chairman, the antecedent land-use plan was shaped by many public meetings, with incorporation of "over 90\%" of the public's suggestions. The ordinance was discussed at further public hearings, and to generate wide understanding the entire draft was published in an area newspaper. Biological Station staff had been involved with the township over several years and regularly attended township association meetings beginning in December 1974. Portions of two Lakeland Reports were reproduced in the Burt Township Association's newsletter.

\section{Planning for Sewer Systems}

A sewer system is a double-edged instrument. On the one hand, as in the case of Crooked Lake, it can remedy the defects of aging and overloading of septic tanks. On the other hand, the presence of a sewer means that land unsuitable for septic tanks is available for development, thus increasing rather than decreasing the ecologic pressure on the lake.

Under the Water Pollution Control Act PL 92-500 of 1972, Section 201 provides for Federal matching fund support in three steps: preliminary planning and evaluation, construction planning, and building of treatment works. Application for the first step had a deadline of September

\footnotetext{
${ }^{4}$ Straitsland Reporter, May 27, 1976, p. 4.
}

1976. A sanitary engineering firm that had installed the Crooked Lake sewer contacted townships throughout the area urging them to take advantage of the planning funds. Engineers from the firm talked to Biological Station personnel on several occasions and incorporated Lakeland $R \boldsymbol{e}$ ports and other material into their planning documents.

During the summer of 1976 Biological Station staff attended hearings on sewer planning for Burt, Mullett, and Walloon lakes and presented information on soil types around these lakes, current water quality, the lake's flushing rate, and the protective value of wetlands. The engineering firm had originally proposed to sewer the entire southern end of the Burt Lake shore with an extension to part of Mullett Lake. As a result of contact with Biological Station personnel and additional public meetings in the fall and winter of 1976 , the proposal shifted to a plan serving only the village of Indian River on the waterway between Burt and Mullett. This position was adopted in the fall of 1977 and illustrated the use of both hard and soft information for an instrumental purpose-cells A and B of the matrix.

\section{Freeway Planning}

For several weeks in late 1975 the planning commission in one county debated the merits of a limited-access freeway proposed by the Michigan Department of State Highways and Transportation to replace two current arteries. Following a public hearing in January 1976 at which sentiment was generally opposed, a chamber of commerce interviewed 100 local businessmen and reported in February that slightly more than half of the businessmen opposed the freeway and a large majority favored improvement of current routes. At this meeting results were also presented from the NMERP social survey conducted in the summer of 1975 from a representative sample of nonwaterfront residents of the area. In this group only one-quarter favored a freeway; the remainder wanted no changes or improvement of existing roads.

The parallels between NMERP data and those from local businessmen provided support for the commission's recommendation that existing highways be improved rather than a freeway constructed. This sequence represents a case of cell $\mathrm{A}$ in the matrix - where a small amount of hard information (along with other input) has directly influenced an instrumental decision to oppose the freeway.

\section{Cooperation among Lake Associations}

Partly as a result of the foregoing activities (passage of the Burt Lake ordinance and hearings on sewer planning) six associations surrounding Burt Lake have moved to form 
a consolidated group for the entire lake. The United Burt Lake Association held its first annual meeting in August 1977. There is little doubt that this development has been stimulated by continued contacts with the Biological Sta-. tion and its output of ecologic information, mainly of soft character. Because the formal move to consolidate (instrumental use) undoubtedly resulted from an increase in environmental understanding (conceptual use), -illustrations of cells $\mathbf{C}$ and $\mathbf{D}$ of the matrix may be inferred.

\section{Principles for Utilization of Environmental Knowledge}

The utilization activities of NMERP have been governed by a series of relatively simple guidelines. It will be helpful to summarize them here and to illustrate them with the preceding examples. These guidelines could be applied by any similar program for the utilization of ecologic knowledge.

Perhaps the broadest generalization is that a multiplicity of mutually reinforcing techniques is needed. Environmental decisions will not be much affected simply by disseminating reports to decision makers. Instead, many types and channels of communication must be employed, over an extended period of time, so that a "climate" of support for needed decisions can be established.

The program therefore (a) identified a population of local "stakeholders" and maintained regular contact with them by repeated mailings; (b) periodically consulted with community leaders on the design and progress of the research program; (c) prepared a series of self-contained information briefs including Lakeland Reports, informational booklets, and articles in local newspapers; (d) maintained regular contact with decision-making bodies, such as the planning commissions of both counties; (e) maintained contacts with lake associations and other civic groups; (f) made direct inputs into local decisions by public testimony at hearings, personal consultation, and contribution to background documents; and $(\mathrm{g})$ made regular use of mass media to publicize the program.

The various outputs contained a mixture of factual or quantitative data (hard information) and general principles and concepts (soft). The Lakeland Reports, the program's primary vehicle for transmitting ecologic information, were designed to present concisely general principles along with factual details, to allow personal identification, to give action implications, to intersperse text with illustrations, and to invite active reader involvement. Such outputs served not only to affect specific actions (instrumental use) but also to build a climate of awareness and under- standing (conceptual). It often appears that conceptual use must precede instrumental-for example, public concern over nutrients in Crooked Lake preceded the decision to alter fish production in the hatchery.

The importance of working through local associations and their leadership cannot be overemphasized. Many of the cases of utilization reported earlier were accomplished by local groups with the aid of information and support supplied by the Biological Station. Public officials are always sensitive to what their constituents will endorse. Private bodies can play a significant role in building public support. For example, voters' approval of the Burt Township ordinance including wetlands protection was the culmination of several years of preparation by the Burt Township Association.

These experiences suggest further guidelines. (a) Effective action by local groups is usually a cumulative process over several years. Accordingly, a scientific facility may need to invest a long period in cultivating such action. (b) Such efforts require wide public participation and compromise. For example, the Burt Township ordinance was preceded by several years spent in the preparation of a land-use plan, which incorporated many of the public's suggestions. A political process of negotiation and compromise is to be expected. (c) The Biological Station and the lake associations offered each other mutual benefits. Station personnel supplied material for association newsletters and speakers for their meetings. In turn, the associations retransmitted reports to their memberships. (d) Local confidence was strengthened by the fact that several members of the Biological Station staff were long-term residents of the area. Although other staff resided elsewhere, they lived in the area the whole summer and cultivated many local contacts. Hence a mixture of insiders and outsiders was effective. Without doubt, the local response could not have been achieved by operating "long distance" (e.g., from an Ann Arbor base).

Among the examples of use cited earlier, some involved specific actions (e.g., the planning commission's rejection of a new freeway), whereas others involved changes in institutions (e.g., adoption of the Burt Lake ordinance and longterm planning for sewer construction). An obvious principle is that the use of knowledge to accomplish institutional changes will have more pervasive and enduring effects than a use which accomplishes a single action.

In conclusion, the utilization activities of the Northern Michigan Environmental Research Program have been guided by a series of familiar principles that can be applied by environmental programs elsewhere in the use of ecologic knowledge. To repeat the broadest generalization: Environ- 
mental decisions will not be much affected if reports are simply disseminated. Instead, many mutually reinforcing channels of communication must be employed to develop a climate of understanding for needed decisions.

\section{Acknowledgments}

This work was supported by Grant No. AEN72-03483 from the National Science Foundation and represents a contribution from the University of Michigan Biological Station. Any opinions, findings, or conclusions expressed in this publication are those of the authors and do not necessarily reflect the views of the National Science Foundation.

\section{Appendix}

List of brief information packages on environmental protection from the University of Michigan Biological Station

Lakeland Report Series. Research and information briefs.

1. NORTHERN MICHIGAN ENVIRONMENTAL RESEARCH PROGRAM. Project objectives. Phenomena of "soapsuds" and "algae blooms" in lakes. 2 pp.

2. PROGRESS REPORT ON SOGIAL SURVEY. Population characteristics and attitudes of water-oriented residents. Concept of "fall overturn" in lakes and map of lake watersheds. $4 \mathrm{pp}$.

3. SHORELINE DEVELOPMENT FACTOR (SDF). Concept of shoreline length and potential for overdevelopment. 3 pp.

4. LAKE STRUGTURE. The size and depth of lakes affect their sensitivity to human development. $6 \mathrm{pp}$.

5. WETLANDS AND WHY THEY ARE IMPORTANT. The four major types of wetlands and their functions in protecting lakes. $6 \mathrm{pp}$.

6. ATTITUDES ABOUT GROWTH. Perceptions and attitudes of water-oriented residents. $8 \mathrm{pp}$.

7. SEASONAL CHANGES IN TEMPERATURE AND OXYGEN IN EMMET AND CHEBOYGAN COUNTY LAKES. $6 \mathrm{pp}$.

8. NUTRIENTS FROM HUMAN USE. Sources of nutrient and their effect on lake eutrophication. 6 $\mathrm{pp}$.

9. THE FUTURE OF NORTHERN MICHIGAN. Results from the social survey of residents and vaca-

\footnotetext{
${ }^{5}$ Additional reports are under preparation in both series and will be available from: Director, Biological Station, University of Michigan, Ann Arbor, Mich. 48109.
}

tioners on their expectations of future change and personal plans for the future. $6 \mathrm{pp}$.

10. WETLANDS: WHY THEY ARE IMPORTANT. A revision of Lakeland Report No. 5 for improved applicability beyond the original study area. $8 \mathrm{pp}$.

11. WETLANDS: UNDERSTANDING AND PROTECTING A VALUABLE RESOURCE. Management considerations for wetlands preservation. $8 \mathrm{pp}$.

12. GREENBELTS: A CIRGLE OF PROTECTION FOR INLAND LAKES. $5 \mathrm{pp}$.

14. INLAND LAKES POLLUTION PROBLEMS: SEPTIC SYSTEMS AND WASTEWATER TREATMENT ALTERNATIVES. $8 \mathrm{pp}$.

Lake Profile Series. Characteristics of specific lakes, cultural and geologic history, present water quality condition, and susceptibility to future change by human impact. Each $10 \mathrm{pp}$.

1. WALLOON LAKE PROFILE. Emmet Co., Mich.

2. BURT LAKE PROFILE. Cheboygan Co., Mich.

3. PROFILE OF CROOKED AND PICKEREL LAKES. Emmet Co., Mich.

\section{Literature Cited}

Caplan, N., A. Morrison, and R.J. Stambaugh. 1975. The Use of Social Science Knowledge in Policy Decisions at the National Level. GRUSK, Institute for Social Research, Univ. of Michigan, Ann Arbor, 63 pp.

Caplan, N., and R. Rich. 1976. "Institutional Insularity and Bureaucratization: The Process and Consequence of Information Policy at the National Level." Paper Delivered at OECD Con ference on Dissemination of Economic and Social Development Research Results, Bogotá, Colombia, June.

Foster, W.L. 1976. Natural Features of the Inland Water Route of Northern Lower Michigan. Univ. of Michigan Biological Station, Pellston, February, 33 pp.

Foster, W.L. 1977. Profile of the Land: Natural Features of the Inland Water Route Region of Northern Lower Michigan (rev. ed.). Univ. of Michigan Biological Station, Pellston, November, $29 \mathrm{pp}$.

Fulton, J.K, and E.W. Say. 1971. Inland Lakes: Analysis and Action. Huron River Watershed Council (also Extension Bulletin E-718, Cooperative Extension Service, Michigan State University), Ann Arbor, 40 pp.

Gannon, J.E., and D.J. Mazur. 1976. Sources of Nutrients (Phosphorus and Nitrogen) for Crooked Lake, Emmet County, Michigan, 1975-76. Special Report to Fish Division, Michigan Department of Natural Resources. Univ. of Michigan Biological Station, Pellston; June 8, 14 pp.

Pelz, D.C. 1977. Utilization of Environmental Knowledge on Northern Michigan. CRUSK, Institute for Social Research, Univ. of Michigan, Ann Arbor, 174 pp.

Rich, R.F. 1977. Uses of social science information by federal bureaucrats: Knowledge for action versus knowledge for understanding. In C.H. Weiss (ed.), Using Social Research in Public 
Policy Making. Lexington Books, Lexington, Mass.: pp. 199 211.

Rich, R.F., and N. Caplan. 1976. "Instrumental and Conceptual Uses of Social Science Knowledge and Perspectives: Means/ Ends Matching Versus Understanding." Paper Delivered at OECD Conference on Dissemination of Economic and Social Development Research Results, Bogotá, Colombia, June.

Say, W.E., M.W. Paddock, J.E. Gannon, and W.L. Foster. 1975 Inland Lake Protection in Northern Michigan. Univ. of Michigan Biological Station, Pellston, September, $40 \mathrm{pp}$. 